\title{
Effect of Potassium on Growth, Fruit Quality Improvements and Resistance to Anthracnose in Field Grown Capsicum (Capsicum Annum L. Cv. 'Hungarian Yellow Wax')
}

\author{
${ }^{1}$ K. S. Somapala, ${ }^{1}$ H. L. D. Weerahewa and ${ }^{2}$ S. Thrikawala \\ ${ }^{1}$ Department of Botany, Faculty of Natural science, The Open University of Sri Lanka \\ ${ }^{2}$ Department of Agriculture and Plantation Management, Faculty of Engineering Technology, \\ The Open University of Sri Lanka
}

\begin{abstract}
Postharvest losses of capsicum crop accounts for 30-40\% of total crop production. It has been shown that postharvest losses of capsicums can be reduced significantly with the application of potassium due to improvements in disease resistance and fruit quality. The objective of this study was to investigate the effect of higher doses of potassium $(K)$ on plant growth, yield and fruit quality parameters and resistance to anthracnose disease of capsicum cv. 'Hungarian Yellow wax'. Three different levels of potassium, Department of Agriculture (DOA) recommended level [180g per bed (control)], double the level (360g per bed) and three times of the level (540g per bed) were applied to the soil in a Randomized Complete Block design. The same experiment was repeated in three farmer fields of Naula Grama Niladhari (GN) division in Dambulla Divisional Secretariat of Matale district of the central province of Sri Lanka. Plant growth parameters were measured at two week intervals, and fruit quality parameters (TSS, Ph, \%TA), fruit physical parameters (length, width, pericarp thickness, fresh weight, firmness and cell wall thickness) were recorded. Finally the resistance to diseases of capsicum fruits was also tested by inoculation of Colletotrichum capsici to the fruits. This study concludes that application of higher doses of potassium improves some plant growth parameters (height and plant diameter at base), fruit physical parameters (fruit length, width, fresh weight, firmness and cell wall thickness). The tripled and doubled the dose of potassium application reduced anthracnose disease by over $75 \%$ and $95 \%$ respectively indicating that higher level of $K$ could have a significant impact in reducing postharvest losses of capsicum in local conditions
\end{abstract}

KEYWORDS: Potassium application, capsicum anthracnose, fruit quality

Corresponding author: H. L. D. Weerahewa, Email: weerahewa@gmail.com 


\section{INTRODUCTION}

Capsicum (Capsicum annum L.) is one of the most consumed vegetable crop in Sri Lanka grown in 3287 ha with an annual production of $14406 \mathrm{mt}$. It has a good demand in the export market with $5.7 \%$ of the production being exported annually (DOA, 2010). The genus Capsicum is counted for a massive postharvest loss due to the disease anthracnose which is caused by Colletotrichum species in both tropical and sub-tropical regions (Pereira et al., 2011; Park et al., 2012). In Sri Lanka, the post harvest loss of capsicum cultivation due to anthracnose disease is estimated around $21-47 \%$ (Rajapakse, 1999). The disease is caused by mainly five Colletotrichum species: C. acutatum, C. capsici, C. gloeosporioides, C. nigrum (Don et al., 2007) and C. coccodes (Johnston and Jones, 1997) in the world while C. gloeosporioides and C. capsicii (Rajapakse and Ranasighe, 2002) are the commonly found species in Sri Lanka.

The control of disease is currently achieved by application of fungicides, which is costly and environmentally hazardous. In addition, growing capsicum in the field involves extensive labor and a high cost of agrochemicals such as, mineral fertilizers and fungicides in order to assure good yield and quality. Meanwhile, there is an increasing demand for no or less chemical applied fresh produce and many researches have been laid on substituting pesticides with non-hazardous and cheaper controlling methods. Pre-harvest application of high doses of potassium $(\mathrm{K})$ has been proven to be effective in decreasing the incidence of many pests and/or diseases in crops (Fuchs and Grossmann, 1972) and thus farmers are advised to apply $\mathrm{K}$ fertilizers to improve crop health (Imas and Magen, 2007; Amtmann et al., 2008). In addition, potassium is involved in yield and quality improvements of fresh produce (Amtmann and Rubio, 2012).

The incidence of anthracnose (Colletotricchum higginsianum) in flowering Chinese cabbage
(Brassica parachinensis) was found to be reduced with increased levels of potassium (Guo et al., 2012). In tomato cv. 'Maheshi' and 'Thilina', the disease was effectively reduced by application of extra dose of potassium (Weerahewa and David, 2015). Moreover, anthracnose, stalk-end rot and freckle disease in banana could be effectively suppressed by twice the recommended dosage of $\mathrm{K}$ (Weerakoon et al., 2005). Further, application of thrice the recommended dose of potassium had shown a significant reduction of stem-end rot in mango variety 'Karuthacolomban' by over $45 \%$ compared to the recommended dosage (Karunanayake, 2008). Application of higher doses of potassium has resulted significant increase in plant growth parameters such as plant length, number of shoots and leaves in egg plant (Fawzy et al., 2007) and in tomato (Nanadal et al., 1998) compared to the control. Application of higher dose of $\mathrm{K}$ resulted increased fruit size, fresh and Effect of potassium on growth, fruit quality improvements and resistance dry weight of bell pepper (Kaya and Higgs, 2003), egg plant (Fawzy et al., 2007) and potato (Khan et al., 2012).

This study was conducted to investigate the impact of application of higher doses of $\mathrm{K}$ on growth and fruit quality of capsicum.

\section{MATERIALS AND METHODS}

\subsection{Study Location}

The study was carried out in farmers fields at NaUla GN division in Dambulla Divisional Secretariat of Matale District of the central province of Sri Lanka.This is located at an altitude of about $380.69 \mathrm{~m}$ above sea level. The soil was flat, with a clay loam texture and $\mathrm{pH}$ of $6.1,0.85 \mathrm{~g} / \mathrm{cm}^{3}$ bulk density, $25.45 \%$ moisture content and $19.85 \%$ soil porosity. The average recorded temperature and relative humidity were $31^{\circ} \mathrm{C}$ and $79 \%$ respectively during the period of study. 


\subsection{Plant Material and Nursery Management}

Seeds of capsicum genotype Capsicum annum 'cv. Hungarian Yellow Wax' from Polo-seed International, Thailand were used for the experiment. Seeds were sown in a 1:1 mixture of well decomposed farmyard manure and top soil and maintained according to the DOA recommendation (DOA, 2011) until transplantation.

\subsection{Treatments and Experimental Design}

Mature four week old seedlings were transplanted in $300 \mathrm{ft}^{2}$ beds with spacing of 15 $\mathrm{cm} \times 30 \mathrm{~cm}$. The basal fertilizer was applied as recommended by the Department of Agriculture. In the first and second top dressings, three potassium [muriate of potash (MOP)] treatments were applied in fact, DOA recommendation [180g per bed- control (K1)], double the recommendation (360g per bed- K2) and three times of the recomendation (540g per bed- K3) along with DOA recommended doses of triple super phosphate (TSP) and urea. Treatments were arranged in a randomized complete block design (RCBD) with three replicates. The experiment was repeated at three locations.

\subsection{Measurement of Growth, and Fruit Quality Parameters}

Five plants from a plant bed were randomly selected for obtaining plant growth parameters. The shoot length, diameter at base, number of leaves and number of branches per plant were measured at two week interval.

Capsicum fruits were harvested at the colour break stage for obtaining physical parameters. From each replicate, fifteen fruits were used to test fruit quality parameters. Fruit length and fruit fresh weight of each harvested fruit were measured and averaged. Fruit width and fruit pericarp thickness were measured by a vernier caliper. Diameter at the maximum width was taken as the fruit width. Fruits were cross sectioned at the maximum width and 3 measurements of pericarp thickness were taken per cross section. Fruit firmness was measured by penetrometer (Model FT 40, Wagner Instruments, Greenwich CT).

Fruit extracts were prepared by crushing five representative fruits per replicate separately using a blender and squeezing the pulp through a muslin cloth. Total soluble solids (TSS) of fruit extracts were measured by a refractometer (Model WZ-113, China) within the range of 0 $32 \%$ Brix and $\mathrm{pH}$ of the extracts was measured using $\mathrm{pH}$ meter (Model IQ150, USA). Aliquots $(5 \mathrm{ml})$ of fruit extracts were titrated against 0.1 $\mathrm{M} \mathrm{NaOH}$ in the presence of phenolphthalein as an indicator and titratable acidity (\%TA) for each sample was determined according to a previously followed procedure (Askar and Trepow, 2013). Three samples from one fruit extract were used to repeat the procedures of measuring TSS, $\mathrm{pH}$ and $\% \mathrm{TA}$.

\subsection{Pathogen Isolation and Identification}

Fruits with anthracnose lesions were collected and surface sterilized with $1 \% \mathrm{NaOCl}$ for 1 minute followed by washing with sterile distilled water. Tissues from lesion areas were then placed on PDA (Potato Dextrose Agar) media and incubated at $27-30^{\circ} \mathrm{C}$. C. capsici was identified by its sickle-shaped conidia, the presence of prominent setae (Sutton, 1992), and its brown colony colour (Rajapakse and Ranasighe, 2002).

\subsection{Assessment of Anthracnose Disease resistance}

Resistance against anthracnose disease was assessed by artificial inoculation of $C$. capsici on fruits and measuring the lesion area for 10 days. Six fruits from each treatment were used for the inoculation study. A spore suspension $\left(10^{5}\right.$ conidia per ml) was prepared by using 7 days old pure cultures of C. capsici and three drops of spore suspension $(20 \mu \mathrm{l})$ were placed per fruit. Inoculated fruits were maintained in moist 
chambers (95-100\% relative humidity) at $28 \pm 2$ ${ }^{\circ} \mathrm{C}$ for 10 days. The average lesion area was calculated for each fruit.

\section{RESULTS}

\subsection{Plant Growth Parameters:}

A significant increase in some of the plant growth parameters were observed with increasing dosage of MOP. In fact, plant height and diameter at base were signifivcantly increased in plants treated at triple the dose of DOA recomendation than that of the control (Table 1). Similarly, application of higher doses of potassium has resulted significant increase in plant growth parameters in egg plent (Fawzy et al., 2007), tomato (Nanadal et al., 1998) and potato (Khan et al., 2012) compared to the control.

\subsection{Fruit Physical Parameters:}

Some fruit physical parameters were significantly improved with increasing MOP application (Table 2). Fruit weight, lenght and width were significantly higher in crops treated with thrice the recomended dose of MOP. However, results are not consistent in significance among three treatment levels. Similar results were bought about by Kiviani et al., (2004) and Akhtar et al., (2010). In addition, Picha and Hall, (1981) has reported that increased application of $\mathrm{K}$ resulted in enhanced yield of tomato fruits through larger proportion of fruit forming flowers. In tomato and kidney bean, $\mathrm{K}$ application significantly increased harvests bean as a result of increased sugar concentrations (Liu et al., 2018). Similarly, the yield and size of tomato, bell pepper, apple and egg plant were improved as a result of soil application of higher doses of potassium (Fawzy et al., 2007; Kaya and Higgs, 2003; Locascio et al., 1997; Nava et al, 2009; Wojcik, 2005). However, the results of the present study are in contradictory to the findings of Loch and Petho (1992).

\subsection{Physicochemical Parameters}

The effect of higher doses of $\mathrm{K}$ application was not significant on either $\mathrm{pH}$ or $\%$ titratable acidity. Yet, application of extra doses of $\mathrm{K}$ has significantly influenced only on total soluble solids where triple the dosage is significantly different from DOA recommendation (Table 3). TSS levesls were increased with increased levels of MOP though the results were not statistically significant and the results were in agreement with the findings of Delgado et al (2004). The increased levels of TSS might be due to induction of sugar synthesis by potassium (Bidari and Hebsur, 2011). However, no significant difference between first and second of application of potassium was observed.

\subsection{Resistance to Anthracnose}

Day of disease initiation and area of lesion development after challange innoculation with C. capsici is given in table 4. Anthracnose disease initiation followed chalanged inoculation with $C$. capsici on capsicum fruits was significantly delayed by the application of extra doses of MOP though there was no significant difference between extra doses of $\mathrm{K}$. The rate of lesion development on fruits of plants treated with higher doses of $\mathrm{K}$ was found to be slower than that of the control fruits (Figure 1). Disease initiation was significanty delayed by the application of extra dose of MOP despite there is no significant difference between higher doses of K. Further, application of extra doses of potassium has significantly suppressed lesion development. MOP. The disease reduction measured in area of lesion development at 10 DAI were $95 \%$ and $74 \%$ in double and triple the recommended levels of application respectively compared to the DOA recommendation.

Nearly $70 \%$ of the studies have reported that $\mathrm{K}$ is an effective mean of controlling numerous bacterial and fungal diseases in crops (Amtmann et al., 2008). The results of the current study provide evidences that soil application of higher doses of $\mathrm{K}$ can significantly decrease anthracnose disease development in field grown 
capsicum caused by $C$. capsici. Similarly the disease caused by $C$. gloeosporioides in tomato, cv. 'Thilina' and 'Maheshi' was effectively controlled by thrise the recomended level of $\mathrm{K}$. (Weerahewa and David, 2015).

However, fruit firmness and cell wall thickness of exocarp were significantly increased with increasing dosages of MOP though there was no significant difference between the control and the treatment level 2 (Table 5). Adequate supply of potassium results thicker cell walls making it harder for disease organisms to penetrate plant cells and establish an infection (IPNI, 2010) and thus, increased fruit firmness and cell wall thickness might have created a physical barrier against the penetration of C. capsici. Anthracnose is one of the major diseases which reduces the fruit quality causing a concidereble postharvest loss in capsicum. Thus, utilizing increased potassium dosage is a valuble option that may be used as an integrated disease management strategy, especially when the cost of fungicide application needs to be reduced.

Table 1. Plant growth parameters of capsicum as affected by potassium treatments

\begin{tabular}{|l|c|c|c|}
\hline & \multicolumn{3}{|c|}{ Potassium Treatments } \\
\hline Parameter & K1 & K2 & K3 \\
\hline Plant height $(\mathrm{cm})$ & $55^{\mathrm{b}}$ & $63^{\mathrm{a}}$ & $66^{\mathrm{a}}$ \\
\hline Diameter at base $(\mathrm{cm})$ & $1.2^{\mathrm{b}}$ & $1.3^{\mathrm{a}}$ & $1.4^{\mathrm{a}}$ \\
\hline No. of branches & $9^{\mathrm{a}}$ & $8^{\mathrm{a}}$ & $8^{\mathrm{a}}$ \\
\hline No. of leaves & $68^{\mathrm{b}}$ & $78^{\mathrm{a}}$ & $63^{\mathrm{b}}$ \\
\hline
\end{tabular}

Means followed by the same letter in each raw are not significantly different at $\mathrm{P} \leq 0.05$. $(n=45$ for plant growth parameters)

Table 2. Fruit physical parameters as affected by potassium treatments

\begin{tabular}{|l|c|c|c|}
\hline \multirow{2}{*}{$\begin{array}{c}\text { Fruit physical } \\
\text { parameter }\end{array}$} & \multicolumn{3}{|c|}{ Potassium Treatments } \\
\cline { 2 - 4 } & K1 & K2 & K3 \\
\hline Length $(\mathrm{cm})$ & $7.9^{\mathrm{c}}$ & $10.6^{\mathrm{b}}$ & $13.1^{\mathrm{a}}$ \\
\hline Width $(\mathrm{cm})$ & $3.1^{\mathrm{b}}$ & $3.1^{\mathrm{b}}$ & $3.5^{\mathrm{a}}$ \\
\hline $\begin{array}{l}\text { Pericarp thickness } \\
\text { (mm) }\end{array}$ & $3.65^{\mathrm{b}}$ & $4.8^{\mathrm{b}}$ & $3.7^{\mathrm{a}}$ \\
\hline Fresh weight $(\mathrm{g})$ & $24.26^{\mathrm{b}}$ & $25.99^{\mathrm{b}}$ & $30.83^{\mathrm{a}}$ \\
\hline
\end{tabular}

Means followed by the same letter in each raw are not significantly different at $\mathrm{P} \leq 0.05$. $(n=45)$
Table 3. Physicochemical parameters of fruits as affected by potassium treatments

\begin{tabular}{|l|c|c|c|}
\hline & \multicolumn{3}{c|}{ Potassium Treatments } \\
\hline & $\mathrm{K} 1$ & $\mathrm{~K} 2$ & $\mathrm{~K} 3$ \\
\hline $\begin{array}{l}\text { Total Soluble Solids } \\
\left({ }^{\circ} \text { Brix }\right)\end{array}$ & $4.67^{\mathrm{b}}$ & $4.72^{\mathrm{b}}$ & $5.13^{\mathrm{a}}$ \\
\hline $\mathrm{pH}$ & $5.12^{\mathrm{a}}$ & $5.17^{\mathrm{a}}$ & $5.1^{\mathrm{a}}$ \\
\hline $\begin{array}{l}\text { \% Titratable acidity }\left(\mathrm{g} \mathrm{L}^{-1}\right. \\
\text { as tartaric acid) }\end{array}$ & $0.05^{\mathrm{a}}$ & $0.06^{\mathrm{a}}$ & $0.06^{\mathrm{a}}$ \\
\hline
\end{tabular}

Means followed by the same letter in each raw are not significantly different at $\mathrm{P} \leq 0.05$. $(n=27)$

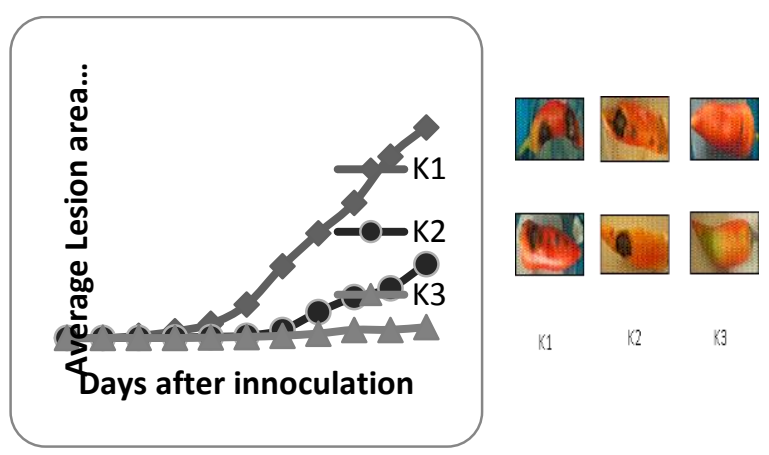

Figure 01: Anthracnose disease lesion development of $\mathrm{K}$ treated capsicum for $10 \mathrm{DAI}$ ( $n=45$ for each treatment)

Table 4. Effect of higher doses of MOP on resistance to anthracnose disease of capsicum fruits after challenged inoculation with $C$. capsici

\begin{tabular}{|l|c|c|c|}
\hline & \multicolumn{3}{|c|}{ Potassium Treatments } \\
\hline & K1 & K2 & K3 \\
\hline $\begin{array}{l}\text { Total lesion area } \\
\text { development for 10DAI } \\
\left(\mathrm{mm}^{2}\right)\end{array}$ & $149.2^{\mathrm{c}}$ & $39.02^{\mathrm{b}}$ & $7.59^{\mathrm{a}}$ \\
\hline $\begin{array}{l}\text { Day of disease initiation } \\
\text { after inoculation }\end{array}$ & $3^{\mathrm{b}}$ & $5^{\mathrm{a}}$ & $5^{\mathrm{a}}$ \\
\hline
\end{tabular}

Means in each column followed by different letters are significantly different at $P \leq 0.05(n=$ 45) according to the DMRT. 
Table 5. Effect of higher doses potassium on fruit characteristics of field grown capsicum fruits

\begin{tabular}{|l|c|c|c|}
\hline \multirow{2}{*}{ Parameter } & \multicolumn{3}{|c|}{ Potassium Treatments } \\
\cline { 2 - 4 } & $\mathrm{K} 1$ & $\mathrm{~K} 2$ & $\mathrm{~K} 3$ \\
\hline Fruit firmness $(\mathrm{N})$ & $16.82^{\mathrm{c}}$ & $18.57^{\mathrm{b}}$ & $20.99^{\mathrm{a}}$ \\
\hline $\begin{array}{l}\text { Cell wall thickness } \\
(\mu \mathrm{m})\end{array}$ & $0.21^{\mathrm{b}}$ & $0.26^{\mathrm{a}}$ & $0.25^{\mathrm{a}}$ \\
\hline
\end{tabular}

Means in each raw followed by different letters are significantly different at $P \leq 0.05(n=45)$ according to the DMRT.

\section{CONCLUSION AND FUTURE WORK}

Potassium was proven to possess beneficial effects on field grown capsicum cv. 'Hungarian Yellow Wax' in some growth parameters, yield and controlling anthracnose disease. Therefore, soil application of increased potassium dosages could be a valuable solution in integrated disease management strategy especially as a substitute for environmentally unsound fungicides. However, potassium does not involve directly in synthesis of physical or chemical components of the plant body. Thus, the reason behind increased fruit cell wall thickness and firmness is quite unclear and might be due to systemically acquired resistance and further studies are required for understanding the exact mechanism.

\section{REFERENCES}

AKHTAR ME, KHAN MZ, RASHID MT, AHSAN Z \& AHMAD SAGHEER. Effects of potash application on yield and quality of tomato (Lycopersicon esculentum Mill.). Pakistan Journal of Botany. 2010; 42: 1695-1702.

AMTMANN A \& RUBIO F. "Potassium in plants." $\quad 2012$. http://onlinelibrary.wiley.com/doi/10.1002/9780 470015902.a0023737/abstract

AMTMANN A, TROUFFLARD S \& ARMENGAUD P. The effect of potassium nutrition on pest and disease resistance in plants. Physiologia Plantarum. 2008; 133(4): 682-691.

ASKAR AA \& TREPOW H. In: Quality Assuarance in Tropical Fruit Processing, Springer Verlang, Newyork USA. 1993; 9-25.

BIDARI BI \& HEBSUR NS. Potassium in relation to yield and quality of selected vegetable crops. Karnataka Journal of Agricultural Sciences. 2011; 24(1): 55-59.

DELGADO R, MARTÍN P, DELÁLAMO M \& GONZÁLEZ MR. Changes in the phenolic composition of grape berries during ripening in relation to vineyard nitrogen and potassium fertilisation rates. Journal of the Science of Food and Agriculture. 2004; 84(7): 623-630.

DOA Capsicum. Retrieved from http://www.agridept.gov.lk/index.php/en/croprecommendations/988, vol. 2011, Department of Agriculture, Sri Lanka. 2010.

DON LD, VAN TT, PHUONG Vy TT \& KIEU PTM. Colletotrichum spp. Attacking on Capsicum Growing in Vietnam. Country Report. In: Oh DG, Kim KT, editors. Abstracts of the First International Symposium on Chilli Anthracnose. Republic of Korea: National Horticultural Research Institute, Rural Development of Administration; 2007. 24.

FAWZY ZF, EL-NEMR MA \& SALEH SA. Influence of levels and methods of potassium fertilizer application on growth and yield of eggplant. Journal of Applied Sciences Research. 2007; 3(1): 42-49.

FUCHS WH \& GROSSMANN F. Nutrition and resistance of crop plants against pathogens and pests. In: Linser $\mathrm{H}$ (ed) Handbuch der pflanzenerna"hrung und düngung. SpringerVerlag, Vienna. 1972; 1(2): 1008-1107.

GUO JX, LIU YT \& YANG X. Effect of Potassium Nutrition on Anthracnose Occurrence and Defense Enzyme Activity in Flowering 
Chinese Cabbage. China Vegetables. 2012; 14: 23.

IMAS P \& MAGEN H. Role of potassium nutrition in balanced fertilization for soybean yield and quality-Global perspective. World. 2007; 92(220.55): 2-38.

International Plant Nutrition Institute. The role of potassium in reducing the incidence of crop diseases. (2010, winter). http://www.ipni.net/ipniweb/pnt.nsf/5a4b8be72a 35cd46852568d9001a18da/bc94c4a2c66bdca68 52577ec0072616c!OpenDocument

JOHNSTON PR \& JONES D. Relationships among Colletotrichum isolates from fruit-rots assessed using rDNA sequences. Mycologia. 1997; 420-430.

KARUNANAYAKE KOL. Natural defense mechanisms in mango fruit and their potential in management of postharvest diseases (Doctoral dissertation), University of Peradeniya, Sri Lanka. 2008; 240.

KAYA C, AK BE \& HIGGS, D. Response of salt-stressed strawberry plants to supplementary calcium nitrate and/or potassium nitrate. Journal of Plant Nutrition. 2003; 26(3): 543-560.

KHAN MZ, AKHTAR ME, MAHMOOD-ULHASSAN M, MAHMOOD MM \& SAFDAR MN. Potato tuber yield and quality as affected by rates and sources of potassium fertilizer. Journal of plant nutrition. 2012; 35(5).

KIVIANI I, BASIRAT MJ \& MALAKOUTI. A comparison between the effects of fertigation and soil application of potassium chloride and soluble SOP on the yield and quality of tomato in Borazjan Region of Boushehr. In: Proc. IPI workshop on potassium and fertigation development in West Asia and North Africa, Rabat Morocco. 2004; 24-28s.
LIU ZH, JIANG LH, LI XL, H“ARDTER R, ZHANG WJ, ZHANG YL \& ZHENG DF. Effect of $\mathrm{N}$ and $\mathrm{K}$ fertilizers on yield and quality of greenhouse vegetable crops. Pedosphere. 2008; 18(4): 496-502.

LOCASCIO SJ, HOCHMUTH GJ, RHOADS FM, OLSON SM, SMAJSTRLA AG \& HANLON EA. Nitrogen and potassium application scheduling effects on drip-irrigated tomato yield and leaf tissue analysis. Hort Science. 1997; 32(2): 230-235.

LOCH J \& PETHO F. Effect of potassium sulphate on the yield of vegetable: In: roc. Potash in Ecosystem, 23rd Colloquium, Potash Institute. Prague. 12-16. 1992; 407-409.

NANADAL JK, RAMESH V \& PANDEY UC. Effect of phosphorus and potassium on growth yield and quality of tomato. Journal of Potassium Research. 1998; 14(1): 44-49.

NAVA G \& DECHEN AR. Long-term annual fertilization with nitrogen and potassium affect yield and mineral composition of Fuji'apple. Scientia Agricola. 2009; 66(3): 377-385.

PARK S, JEONG WY, LEE JH, KIM YH, JEONG SW, KIM GS, BAE DW, LIM CS, JIN JS, LEE SJ \& SHIN SC. Determination of polyphenol levels variation in Capsicum annuum L. cv. chelsea (yellow bell pepper) infected by anthracnose (Colletotrichum gloeosporioides) using liquid chromatography-tandem mass spectrometry. Food Chemistry. 2012; 130: 981985.

PEREIRA MJZ, MASSOLAJÚNIOR NS, SUSSEL AAB, SALA FC, COSTA CP \& BOITEUX LS. Reação de acessos de Capsicum e de progênies de cruzamentosinterespecíficos a isolados de Colletotrichum acutatum. Horticultura Brasileira. 2011; 29:569-576.

PICHA DH \& HALL CB. Influences of potassium, cultivar, and season on tomato 
graywall and blotchy ripening. J. Amer. Soc. Hort. Sci. 1981; 106:704-708.

RAJAPAKSE RGAS. Mode of anthracnose development in chili (Capsicum annum L.) pods. Annals of the Sri Lanka Department of Agriculture. 1999; 1: 247-266.

RAJAPAKSE RGAS \& RANASINGHE JADAR. Development of variety screening method for anthracnose disease in chili. Tropical Agricultural Reseach and Extention. 2002; 5:711.

SUTTON BC. The genus Glomerella and its anamorph Colletotrichum. In: Colletotrichum : Biology, pathology and control. (Bailey JA \& Jeger MJ, Eds.). CAB International, Wallingford, Oxon, UK. 1992; 1-26.

WEERAHEWA D \& DAVID D. Effect of silicon and potassium on tomato anthracnose and on the postharvest quality of tomato fruit (Lycopersicon esculentum Mill.). J.Natn. Sci. Foundation Sri Lanka. 2015; 43 (3): 271-278.

WEERAKOON WRWMAU, Abayasekara CL \& Adikaram NKB. The Effect of Soil Potassium on Postharvest Fungal Diseases of Banana. Proceedings and abstracts of University of Peradeniya Research sessions. 2005; 10, 94.

WÓJCIK P, LIBEK A, KAUFMANE E \& SASNAUSKAS A. Effect of foliar potassium sprays on apple tree yielding, and fruit quality under conditions of low soil potassium availability. In Proceedings of the international scientific conference: Environmentally friendly fruit growing, Polli, Estonia,Tartu University Press. 2005; 44-50. 